\title{
Effect of transitioning to automatic milking systems on producers' perceptions of farm management and cow health in the Canadian dairy industry
}

\author{
C. Tse, ${ }^{*}$ H. W. Barkema, ${ }^{*}$ T. J. DeVries, $†$ J. Rushen, $\ddagger$ and E. A. Pajor*1 \\ *Department of Production Animal Health, University of Calgary, Calgary, AB T2N 4N1, Canada \\ †Department of Animal Biosciences, University of Guelph, Guelph, ON N1G 2W1, Canada \\ ¥Faculty of Land and Food Systems, University of British Columbia, Vancouver, BC V6T 1Z4, Canada
}

\begin{abstract}
Automatic milking systems (AMS), or milking robots, are becoming increasingly common, but there is little documentation of how AMS have affected farms as a whole and what challenges and benefits producers are experiencing during their transition to AMS. The objective of this national survey was to document the effect of transitioning to AMS on producer perceptions of change in housing, farm management, and cow health. In total, 217 AMS producers were surveyed from 8 Canadian provinces. Median time since transition for respondents was 30 mo. The mean number of lactating cows per robot was 51 cows, with a median of 2 AMS units per farm. Fifty-five percent of producers built a new barn to accommodate the AMS. Changing housing systems was necessary for $47 \%$ of producers, not necessary for $50 \%$, and not applicable to $3 \%$ (as the AMS farm was their first farm). Cleaning and feeding practices remained the same. Overall, farms increased herd size from a median of 77 to 85 lactating cows with the transition to AMS. After the transition to AMS, $66 \%$ of producers changed their health-management practices. Producers reported either a decrease or no change in rate of clinical mastitis. Reports on change in rate of lameness and total bacterial count varied. Conception rate was reported to have increased for $63 \%$ of producers. Culling rate was perceived to have stayed the same for $59 \%$ of producers. Overall, producers perceived their transitions to AMS as successful. Findings from this project provide a benchmark of the effects of AMS on important aspects of Canadian dairy farming, as well as provide producers, AMS manufacturers, veterinarians, and dairy advisors with more detailed knowledge on what to expect when transitioning to AMS.
\end{abstract}

Received May 27, 2016.

Accepted October 28, 2016.

${ }^{1}$ Corresponding author: eapajor@ucalgary.ca
Key words: robotic milking, adoption, precision dairying

\section{INTRODUCTION}

When functioning optimally, an automatic milking system (AMS) permits cows to voluntarily visit a robotic milking unit multiple times per day to be milked without requiring human labor. Demonstrated benefits of AMS include increased milk production, improved cow comfort, a more flexible lifestyle for producers (de Koning, 2010), less labor for milking (Hansen, 2015), as well as improved cow health and more interesting or less routine activities for the producer (Jacobs and Siegford, 2012; Woodford et al., 2015). However, an AMS has higher capital costs (Wade et al., 2004), requires producers to be on-call, and changes management to be more data-based (Butler et al., 2012). Profitability or labor savings with AMS varies depending on the management capabilities of producers (van't Land et al., 2000).

Although Europe has the highest concentration of AMS dairy farms, this technology is becoming increasingly common in Canada (Barkema et al., 2015). The proportion of dairy farms in Canada that use AMS has grown from $5.6 \%$ in 2014 to $6.8 \%$ in 2015 (Canadian Dairy Information Centre, 2016). Despite this growing popularity, little documentation exists on how AMS has affected North American farms as a whole (inclusive of cow health, milk parameters, management, housing, and dairy producers).

Several AMS survey studies have been published (e.g., Helgren and Reinemann, 2006; Rodenburg and House, 2007; Rousing et al., 2007; Molfino et al., 2014; Moyes et al., 2014; Tousova et al., 2014), but many of these are non-Canadian studies that focus on a very specific aspect of dairy farming. The Canadian dairy industry is different from that of the United States and European Union in average herd size, milk price, and animal welfare standards (Barkema et al., 2015), sug- 
gesting that AMS studies conducted abroad may not necessarily be reflective of the Canadian dairy industry. Furthermore, few published AMS studies focus on producers' perceptions of change with the transition to AMS and comprehensively describe the effects of adopting AMS on farms.

The objective of our study was to determine how producers perceive the transition to AMS in terms of resulting changes in housing, farm management, and cow health. Other topics addressed in the survey, as described below, will be reported in additional publications.

\section{MATERIALS AND METHODS}

This survey study received institutional human ethics certification before contacting participants (University of Calgary, certification no. REB14-0149_MOD1).

\section{Farm Selection and Data Collection}

Contact information for AMS producers was acquired through Alberta Milk (Edmonton, AB, Canada) and Dairy Farmers of Manitoba (Winnipeg, MB, Canada), which are provincial milk boards, as well as through Lely Canada (Woodstock, ON, Canada) and DeLaval Canada (Peterborough, ON, Canada). We obtained contact information for 530 Canadian AMS producers. All 530 producers in our sampling frame were contacted and data were only collected on those willing to participate. Participating AMS farms in the study were from British Columbia (BC; $\mathrm{n}=8)$, Alberta $(\mathbf{A B} ; \mathrm{n}$ $=43)$, Saskatchewan ( $\mathbf{S K} ; \mathrm{n}=7)$, Manitoba (MB; $\mathrm{n}=12)$, Ontario (ON; $\mathrm{n}=73)$, Quebec $(\mathbf{Q C} ; \mathrm{n}=$ 66), New Brunswick, and Nova Scotia (Table 1). The latter 2 provinces were grouped together due to the smaller sample size per province, and are referred to as the Maritimes $(\mathrm{n}=7)$. The AMS farms in Prince Edward Island and Newfoundland were not surveyed because AMS producers from these provinces could not be reached. The participating farms were surveyed by telephone, email, and in person from May 2014 to the end of June 2015. Producers' consent was received before surveys were conducted. Respondents were given the option to stop the survey at any point, in which case those surveys were excluded.

The study consisted of a 2-part survey. All producers were initially contacted by phone with the general survey (defined below). After completing the general survey, producers who were interested were emailed a link to the second part of the survey with follow-up questions. Producers that could not be contacted by phone (i.e., if only an email address was provided) were emailed a link to the combined survey (defined below)

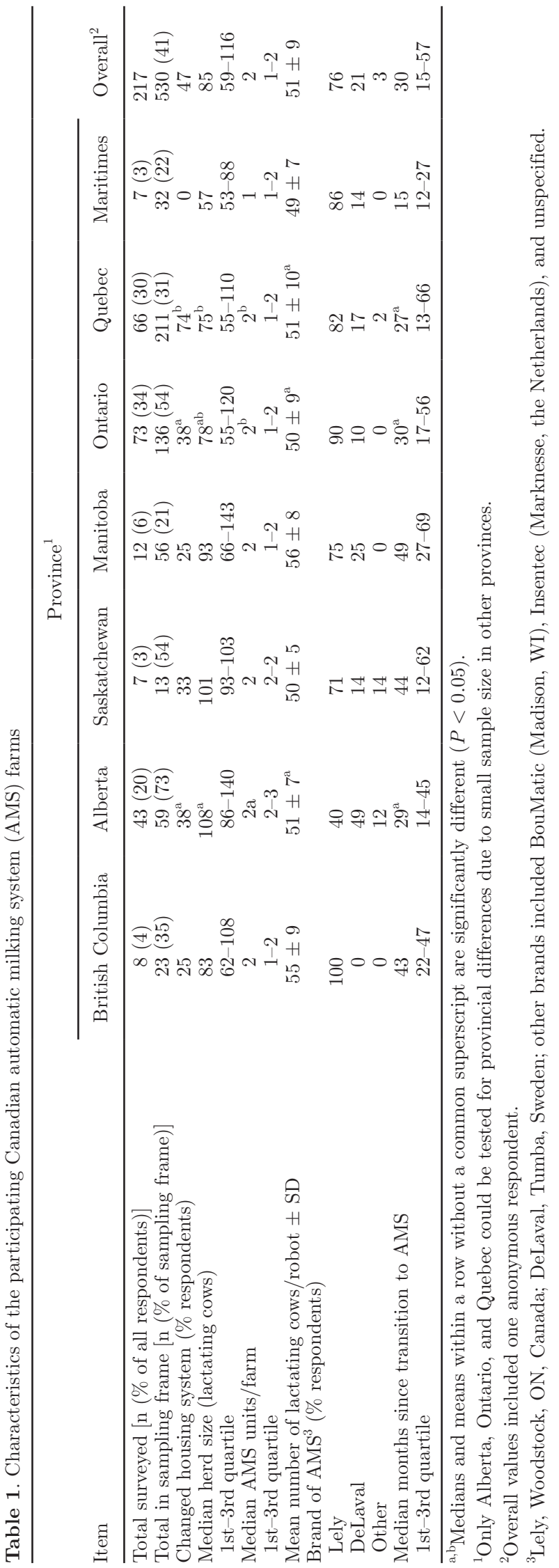

Journal of Dairy Science Vol. 100 No. 3, 2017 
that contained the initial general survey and follow-up questions; the response rate was $41 \%$. Producers who used to operate an AMS farm, but later abandoned the technology, were not included in the study $(\mathrm{n}=$ $3)$. Producers were not selected based on how long they had been operating with AMS. Including a range of producers from the earliest to the newest adopters provided a spectrum of how the transition process has changed with time, thereby offering additional comparative detail.

\section{General Survey, Follow-Up, and Combined Survey}

A mixed-methods survey (titled "The General Survey"; Supplemental File S1, https://doi.org/10.3168/ jds.2016-11521) was developed to obtain information on factors that may have been affected by transitioning to AMS (changes to the facility, employee management, milk production and quality, milking labor management), current milking statistics (average number of milkings per day), cow training, challenges and solutions experienced during the transition, changes in quality of life, and level of satisfaction with their AMS. Questions from this survey were also made available as part of a more detailed survey called "The Combined Survey" (Supplemental File S2, https://doi.org/10.3168/ jds.2016-11521). The combined survey contained all questions from the general survey and more detailed questions on the topics covered in the general survey, in addition to new questions related to cow health- and milk-recording programs. The second part of the survey was provided as a follow-up to the general survey (i.e., the follow-up solely consisted of the questions unique to the combined survey). The question-answer formats ranged from single choice of multiple options, multiple choices of multiple options, fill in the blank, and free form open-ended questions.

The number of respondents per question varied depending on which survey the question was presented in and because respondents were given the option to answer or skip any question. The total number of respondents for the general survey questions was 217 . The total number of respondents for the follow-up questions, or the questions specific to the combined survey, was 69.

\section{Statistical Analyses}

All statistical analyses were performed with $\mathrm{R}$ version 3.2.2 (The R Foundation for Statistical Computing Platform, 2015, Vienna, Austria). Statistical significance was considered at a $P$-value $<0.05$. Due to the exploratory nature of the project, the data analyses primarily included descriptive statistics (means, SD, medians, 1st-3rd quartiles, percentages). Results with normal distribution are presented as means \pm SD. Results with non-normal distribution are presented as medians with interquartile range (IQR; 1st-3rd quartiles).

In cases where provincial comparisons of results were made, only provinces with $>10$ respondents were included. Comparisons of the brand were also made; however, due to the small sample sizes of Insentec (Marknesse, the Netherlands) and BouMatic (Madison, WI) users, comparisons were only made between Lely and DeLaval users. Comparisons between categorical data (e.g., when comparing perceptions of change in lameness, which was answered as either increased, decreased, or stayed the same, after transition by brand) were computed with chi-squared test or, for cases that involved frequency counts of less than 5, Fisher's exact test. Differences between paired groups (e.g., differences in herd size, number of employees, and time devoted to milking-related activity) were analyzed by using a paired $t$-test. Comparisons between normal group means were analyzed with ANOVA and Tukey's post-hoc procedure, whereas Kruskal-Wallis test with Dunn's post-hoc test was used for non-normal group means and ranked variables. Associations between variables were assessed using Pearson correlation coefficient for data with normal distributions, whereas associations between data with non-normal distributions were assessed with Spearman's rank correlation. When analyzing variables with time since transition to AMS, respondents in their first $2 \mathrm{yr}$ of transition were grouped together and compared with those who transitioned $>24$ mo ago. A 2-yr time frame was chosen based on the average transition periods used in AMS literature when comparing milking variables before and after the adoption of AMS, and as a result of sample sizes available from our data set.

Inductive, thematic analysis was used to analyze open-ended questions. In other words, responses for open-ended questions were coded for themes (patterns across the data set) that were then quantified with the purpose of describing how common those themes were among our respondents (Green and Thorogood, 2013).

\section{RESULTS}

\section{Respondent Demographics}

Overall, 217 out of 530 AMS producers in our sampling frame were surveyed in 8 provinces across Canada (Table 1). Seven farms $(3 \%)$ had never owned or operated a dairy farm before their current AMS dairy farm. The range for time since transitioning to AMS was 1 to 170 mo. Median age of Lely robots was 29 mo (IQR 
$=15-53 \mathrm{mo}$ ) and median age of DeLaval robots was $34 \mathrm{mo}(\mathrm{IQR}=21-68 \mathrm{mo})$. Herd size (lactating cows) ranged from 35 to 550 cows. Median herd size was 85 cows, with no differences between brands.

Results represent information provided by full owners (49\%), part owners (48\%), and employees responsible for the herd $(3 \%)$. Primary decision makers, or producers who were the head of the farming operation, created the larger portion of the sample (89\%). Sixty-nine percent of producers had complete or partial college or university education. Survey respondents consisted mostly of males (81\%). Twenty-seven percent of producers were $<35$ yr of age, $28 \%$ were between 35 and $45,30 \%$ were between 46 and 56 , and $15 \%$ were $>56 \mathrm{yr}$ old. We found no difference in response rates between age groups.

\section{Housing, Farm Management, and Feed Practices}

When transitioning to AMS, 55\% of producers (118 of 214 respondents) built new barns. Of these, $71 \%$ also changed housing systems. Of the 96 producers (45\%) who did not build a new barn, only 16 producers (17\%) changed housing system. Overall, $53 \%$ of respondents did not change housing system. For those who changed housing system, $86 \%$ switched from tiestall to freestall, $5 \%$ from bedded-pack to freestall, and $10 \%$ from tiestall or freestall to bedded-pack. A larger percentage of QC producers had to change housing system compared with producers in $\mathrm{AB}$ and $\mathrm{ON}$ (Table 1). Freestall AMS barns were more predominant (91\%) than bedded-pack AMS barns (9\%). Most farms (90\%) used a free-flow traffic system rather than a directed traffic system $(10 \%)$.

Median lactating-cow herd size increased by $10 \%$ from $77(\mathrm{IQR}=55-110)$ to $85(\mathrm{IQR}=58-116)$ lactating cows after transitioning to AMS $(P=0.002)$. Forty percent of farms had 1 robot, $43 \%$ had 2, $10 \%$ had 3, and $7 \%$ had more than 4 robots. Mean $( \pm \mathrm{SD})$ number of cows per robot was $51 \pm 9$ (range $=27-75$ cows/ robot; Figure 1). Most AMS producers (64\%) managed their lactating cows in 1 group; however, of the $60 \%$ of farms that had $>1$ AMS, $60 \%$ had more than 1 group; the number of groups ranged from 1 to 5 . For those who managed their lactating cows in multiple groups ( $\mathrm{n}=25$ respondents), 68\% reported having specific criteria for grouping. Criteria included separating out fresh, first lactation, and $2+$ lactation cows (50\% of respondents); separating special needs and older lactating cows from problem-free and younger lactating cows (19\%); sorting by size and age (13\%); sorting by milking speed and milking visit frequency (13\%); and separating their best pedigree cows $(6 \%)$.
The farms had a median of 1.0 cows/stall $(\mathrm{IQR}=$ 0.8-1.0 cows/stall). Lying stalls had a median width of $122 \mathrm{~cm}(\mathrm{IQR}=117-122 \mathrm{~cm})$. Rubber mats, mattresses, or water mattresses were more commonly used as stall bases than the use of deep-bedding on AMS farms (78 vs. $22 \%$, respectively). Of the rubber mat, mattress, or water mattress users $(\mathrm{n}=54$ respondents $)$, $96 \%$ used bedding on top of the mat or mattress. Half of the producers who used bedding on top of stall mats or mattresses used shavings or sawdust, whereas the other half used other bedding (e.g., straw, manure, or gypsum bedding). Stalls were cleaned out (i.e., dirty bedding and manure scraped out) a median of twice a day (IQR $=2-3$ times/d), and fresh bedding was added as often as once a day to once every $3 \mathrm{wk}$. Alleyways were cleaned a median of 8 times/d (IQR = 6-12 times/d). Automatic manure scrapers were more common on AMS farms (81\%) than the use of slatted floors $(15 \%)$ or scraping by tractor or skid-steer $(4 \%)$.

After transitioning to AMS, $36 \%$ of producers (14 of 39 respondents) changed feeding systems (e.g., individual components to a mixed ration). At the time of the survey, $83 \%$ of AMS farms provided a mixed ration and $17 \%$ provided individual feed components. The number of times feed was delivered to cows stayed the same for $74 \%$ of farms after transition to AMS, decreased for $14 \%$, and increased for $12 \%$. Feed was delivered to the feed bunk a median of 2 times/d (IQR $=1-2$ times/d). The frequency that feed was pushed up to the bunk remained the same for $59 \%$ of farms, increased for $38 \%$, and decreased for $2 \%$. Feed was pushed up in the feed bunk 4 times/d (IQR $=2-9$ times/d). The mean amount of space provided per cow along the feed bunk was $61 \pm 21 \mathrm{~cm} /$ cow. Headlocks were more common on AMS farms (55\% of respondents) than rails $(33 \%)$ or

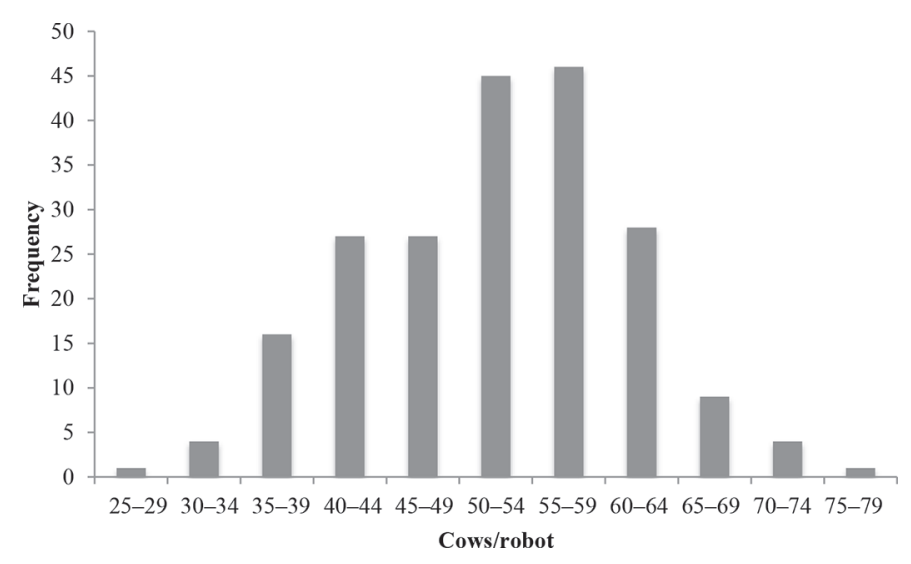

Figure 1. Histogram of number of cows/robot on automated milking system (AMS) farms, where median number of cows/robot was 52 (range of 27 to 75 cows; 208 respondents). 
other feed barriers, such as feed stalls (12\%). Farms had a median of 1.0 headlock/cow (IQR $=0.8-1.1$ headlocks/cow), with median headlocks widths of $61 \mathrm{~cm}$. Between water troughs, bowls, or the use of both, the most common water delivery method on AMS farms was water troughs, which were used by $90 \%$ of farms. We found a median of 26 cows/trough $(\mathrm{IQR}=20-30$ cows/trough). Farms that used both troughs and bowls were not included in calculating this median.

\section{Cow Health}

General Health. Since transitioning to AMS, $66 \%$ of producers had changed their health-management practices. Most producers (80\%) perceived that illness detection was easier with an AMS because of the amount of information the robots provide on each animal (e.g., udder health reports, cow weight and temperature measurements, milking reports, activity and rumination reports; $77 \%$ of respondents) and because of the alarms that notify producers of issues (23\% of respondents). When asked if AMS had made health detection more difficult, $19 \%$ of producers responded "yes." Responses did not differ by age of robots, although overall percentage of producers who reported that health detection was more difficult was lower for Lely owners versus DeLaval owners (Table 2). The producers who found health detection more difficult in AMS indicated difficulties as a result of no longer seeing every cow (and her udder) twice a day (67\% of respondents) and needing to rely on technology (i.e., the AMS) to detect most health issues (33\% of respondents). Table 3 summarizes health issues that producers reported occurring or improving since the transition to AMS (in 2 separate open-ended questions): the most common health issues that were reported to have occurred were lameness and mastitis, whereas the most common health issues that improved were mastitis, reproduction or fertility (e.g., heat detection, pregnancy rates), and lameness. Table 4 summarizes results of multiple-choice questions that asked if various health issues increased, decreased, or stayed the same after transition to AMS. We observed no differences in perceptions of change in rates of lameness, mastitis, fertility, and culling according to the time since transition (Table 4).

Lameness. Rate of lameness after transitioning to AMS was reported to have decreased for $42 \%$ of producers, stayed the same for $38 \%$, and increased for $20 \%$. We found no statistical differences in these proportions. Forty-seven percent of producers changed housing systems at the same time as transitioning to AMS. The proportion of these producers that noticed an increase in lameness ( $17 \%$ of respondents) was greater than those that experienced an increase in lameness but did not change housing system (5\% of respondents; $P<$ 0.001). Producers reported an increase in milk yield despite their perceived change in lameness; we observed no difference in the distribution of producers who stated an increase in milk yield in tandem with an increase ( $21 \%$ of respondents), a decrease (44\%), or no change in lameness (35\%). Since transitioning to AMS, $77 \%$ of farms indicated that they have been more able to detect lame cows as a result of having more time observing cows and automatic detection (e.g., lame cows become fetch cows). Farms reported to have implemented various management practices, such as footbath protocols, hoof trimming, and improving cow comfort to deal with lameness (Figure 2). Thirty percent of producers reported that lame cows were culled more often after transitioning to AMS.

Mastitis. Rate of clinical mastitis was reported to have decreased for $49 \%$ of producers, stayed the same for $38 \%$, and increased for $13 \%$. We observed no difference between proportions of producers who reported a decrease or no change. There were more producers who reported an increase in milk yield in tandem with a decrease in mastitis (54\% of respondents), compared with those who reported an increase in milk yield along with an increase $(13 \%)$ or no change in mastitis (33\%; $P=0.002)$. The most common method used on AMS farms of detecting clinical mastitis was to rely on AMS-generated reports on milk conductivity, blood in milk, change in production, and SCC for alarms, and to follow-up with a manual check (either using a California mastitis test or manual stripping of milk). Reported change in bacterial count varied with no statistical difference, with $40 \%$ of producers perceiving no change, $26 \%$ a decrease, and $34 \%$ an increase. We found a difference in the distribution of producers who reported a change in bacterial count between Lely and DeLaval producers $(P=0.01)$. The largest proportion of DeLaval producers reported an increase in bacterial count (55\% DeLaval vs. 21\% Lely), whereas the largest proportion of Lely producers reported no change $(52 \%$ Lely vs. $18 \%$ DeLaval). Thirty-eight percent of producers reported that mastitis cows were more likely to be culled after transitioning to AMS.

Fertility. Conception rate was reported to have increased for $63 \%$ of producers, stayed the same for $31 \%$, and decreased for $6 \%$. The proportion of producers who reported an increase was significantly greater than proportions of the other categories $(P<0.001)$. Ninety percent of AMS farms used activity or behavior monitors. The most common monitors used were activity collars (used by $51 \%$ of farms) and combination activity and rumination collars ( $47 \%$ of farms). Leg activity monitors were only used by $2 \%$ of farms. The approach to heat detection changed for $63 \%$ of AMS farms. Those 
Table 2. Percentage of producers by brand of automated milking system (AMS; Lely, Woodstock, ON, Canada; DeLaval, Tumba, Sweden) organized by months since transition, with changes in health management after transitioning to AMS

\begin{tabular}{|c|c|c|c|}
\hline \multirow[b]{2}{*}{ Item and months since transition ${ }^{1}(\%)$} & \multicolumn{2}{|c|}{ Brand } & \multirow[b]{2}{*}{ Overall $^{2}$} \\
\hline & Lely & DeLaval & \\
\hline \multicolumn{4}{|l|}{ Changed health management after transition } \\
\hline$\leq 24 \mathrm{mo}^{3}$ & 59 & 100 & 69 \\
\hline$>24 \mathrm{mo}^{4}$ & 65 & 69 & 66 \\
\hline Overall mean & 63 & 77 & 68 \\
\hline \multicolumn{4}{|c|}{ Health detection has become easier with $\mathrm{AMS}^{5}$} \\
\hline$\leq 24 \mathrm{mo}$ & 76 & 100 & 83 \\
\hline$>24 \mathrm{mo}$ & 88 & 69 & 81 \\
\hline Overall mean & 84 & 77 & 82 \\
\hline \multicolumn{4}{|c|}{ Health detection has become harder with $\mathrm{AMS}^{5}$} \\
\hline$\leq 24 \mathrm{mo}$ & 6 & 20 & 9 \\
\hline$>24 \mathrm{mo}$ & 12 & 44 & 24 \\
\hline Overall mean & $10^{\mathrm{a}}$ & $38^{\mathrm{b}}$ & 19 \\
\hline \multicolumn{4}{|c|}{ Changed approach to heat detection with AMS } \\
\hline$\leq 24 \mathrm{mo}$ & 53 & 50 & 54 \\
\hline$>24 \mathrm{mo}$ & 73 & 67 & 71 \\
\hline Overall mean & 65 & 62 & 65 \\
\hline \multicolumn{4}{|l|}{ More able to detect lame cows with AMS } \\
\hline$\leq 24 \mathrm{mo}$ & 76 & 100 & 83 \\
\hline$>24 \mathrm{mo}$ & 77 & 69 & 74 \\
\hline Overall mean & 77 & 77 & 77 \\
\hline \multicolumn{4}{|l|}{ More likely to cull lames cows with AMS } \\
\hline$\leq 24 \mathrm{mo}$ & 18 & 67 & 29 \\
\hline$>24 \mathrm{mo}$ & 31 & 31 & 31 \\
\hline Overall mean & 26 & 41 & 30 \\
\hline \multicolumn{4}{|c|}{ More likely to cull cows with mastitis with AMS } \\
\hline$\leq 24 \mathrm{mo}$ & 29 & 50 & 38 \\
\hline$>24 \mathrm{mo}$ & 38 & 44 & 40 \\
\hline Overall mean & 35 & 45 & 39 \\
\hline
\end{tabular}

$\overline{\mathrm{a}, \mathrm{b}}$ Means within a row without a common superscript are significantly different $(P<0.05)$.

${ }^{1}$ There were no differences in proportions for each item by time since transition (within each brand).

${ }^{2}$ Overall proportions included respondents with other brands and anonymous responses.

${ }^{3}$ Lely: $\mathrm{n}=17$ and DeLaval: $\mathrm{n}=6$.

${ }^{4}$ Lely: $\mathrm{n}=26$ and DeLaval: $\mathrm{n}=16$.

${ }^{5}$ Respondents were given the option of answering each of these questions separately (i.e., a producer could answer "yes" or "no" to both questions).

producers reported relying on computer information to reveal heats and less on visual observations of heat. Activity or behavior monitors were the primary tools for heat detection on $76 \%$ of AMS farms. Methods of heat detection used by the other $24 \%$ of respondents included solely visual observations for heat, use of a timed AI program, and hormone testing with Herd Navigator, software that aims to improve monitoring and intervention in reproduction, udder health, feeding, and feeding-related conditions (Herd Navigator; Lattec I/S, Hillerød, Denmark). Although the main use for activity or behavior monitors was heat detection, some farms also used monitors to detect metabolic disorders, lameness, and mastitis.

Culling. Culling rate was reported to have stayed the same for $59 \%$ of producers, increased for $25 \%$, and decreased for $16 \%$. The proportion of producers who reported no change in culling rate was significantly greater than proportions of the other categories $(P<$ $0.001)$. We found a difference in the distribution of reported change in culling rate between Lely and DeLaval producers $(P=0.003)$. More Lely producers perceived no change in culling rate than DeLaval producers (45 vs. $14 \%$ ), and more DeLaval than Lely producers perceived an increase in culling rate (17 vs. $7 \%$ ). Median percentage of a lactating herd culled because of the transition was $2 \%(\mathrm{IQR}=0-4 \%)$. The most common reasons for culling after the transitioning to AMS were reproduction or fertility issues, poor udder health, lameness and other feet or leg issues, and teat placement or udder conformation (Table 5).

\section{DISCUSSION}

Ours is the first study to provide comprehensive information regarding the perceived effects of transition- 
Table 3. Health issues that have occurred or improved since transitioning to automated milking system (AMS; respondents listed $\geq 1$ health issue that had occurred or improved on their farm)

\begin{tabular}{lcc}
\hline & & Number of \\
Item & Respondents \\
& respondents & $(\%)$ \\
\hline Health issues that have occurred since transition (52 respondents) & 32 & 62 \\
Lameness & 20 & 38 \\
Mastitis & 13 & 25 \\
None & 6 & 12 \\
Increased SCC & 6 & 12 \\
Other & 5 & 10 \\
Reproduction and fertility & 5 & \\
Health issues that have improved since transition (61 respondents) & 25 & 41 \\
Mastitis & 21 & 34 \\
Reproduction and fertility & 15 & 25 \\
Lameness & 7 & 11 \\
Udder health & 7 & 11 \\
None & 6 & 10 \\
Cow comfort & 5 & 8 \\
SCC & 4 & 7 \\
Less displaced abomasum & 4 & 5 \\
Other & & 5 \\
Body condition & 3 & 3 \\
Kransition cow health & 3 & 2 \\
\hline
\end{tabular}

${ }^{1}$ Other health issues that have occurred since transition included afterbirth, decreased transition cow health, increased total bacterial count, more muscle injuries, metritis, and ketosis.

${ }^{2}$ Other health issues that have improved since transition included fewer injuries, earlier detection of sick cows, less milk leakage, and rumination activity.

ing to AMS on housing, farm management (inclusive of feeding and cleaning practices), and cow health. The majority of producers perceived a positive transition to AMS. Farms were able to increase herd size while making slight changes to cleaning and feeding practices. Changing health-management practices with AMS was necessary for most producers, but the majority reported health detection to be easier. Many producers reported an increase in conception rate, a slight effect on mastitis, and no difference in culling rate. We found no difference in the proportions of producers who per-

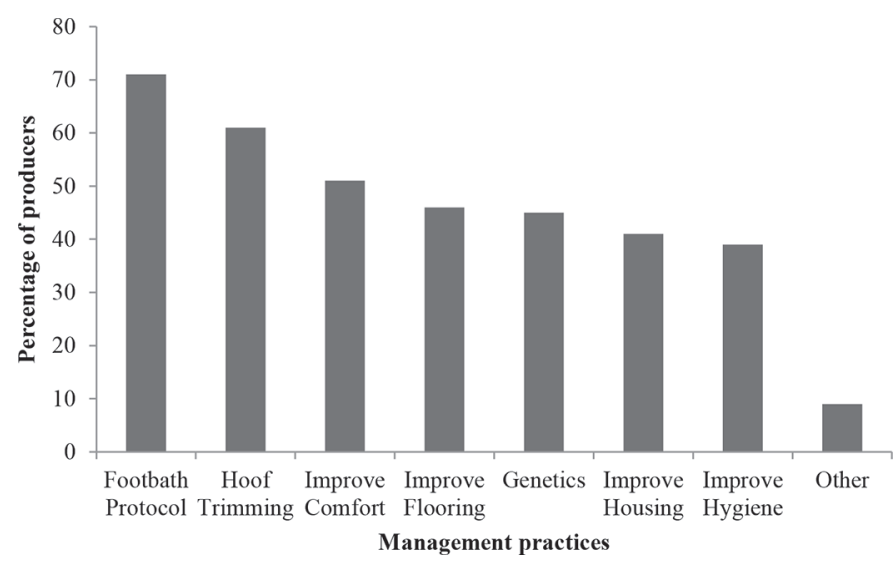

Figure 2. Management practices implemented to deal with lameness on automated milking system (AMS) farms (69 respondents per item).
Table 4. Percentage of producers with respective perceptions of change in cow health after transitioning to automated milking system (AMS), organized by months since transition to AMS $(n=24$ respondents for $\leq 24 \mathrm{mo}, \mathrm{n}=42$ respondents for $>24 \mathrm{mo}$ )

\begin{tabular}{|c|c|c|c|}
\hline \multirow[b]{2}{*}{ Months since transition ${ }^{1}$} & \multicolumn{3}{|c|}{$\begin{array}{l}\text { Perceptions of change } \\
\text { (\% respondents })\end{array}$} \\
\hline & Increased & Decreased & $\begin{array}{l}\text { Stayed } \\
\text { the same }\end{array}$ \\
\hline \multicolumn{4}{|l|}{ Rate of lameness } \\
\hline$\leq 24 \mathrm{mo}$ & 21 & 54 & 25 \\
\hline$>24 \mathrm{mo}$ & 21 & 36 & 43 \\
\hline Overall mean & $20^{\mathrm{a}}$ & $42^{\mathrm{a}}$ & $38^{\mathrm{a}}$ \\
\hline \multicolumn{4}{|l|}{ Rate of clinical mastitis } \\
\hline$<24$ mo & 4 & 42 & 54 \\
\hline$>24 \mathrm{mo}$ & 17 & 52 & 31 \\
\hline Overall mean & $13^{\mathrm{b}}$ & $49^{\mathrm{a}}$ & $38^{\mathrm{a}}$ \\
\hline \multicolumn{4}{|l|}{ Bacterial count of milk } \\
\hline$<24$ mo & 25 & 29 & 46 \\
\hline$>24 \mathrm{mo}$ & 39 & 24 & 37 \\
\hline Overall mean & $34^{\mathrm{a}}$ & $26^{\mathrm{a}}$ & $40^{\mathrm{a}}$ \\
\hline \multicolumn{4}{|l|}{ Conception rate } \\
\hline$\leq 24 \mathrm{mo}$ & 71 & 0 & 29 \\
\hline$>24 \mathrm{mo}$ & 61 & 10 & 29 \\
\hline Overall mean & $63^{\mathrm{a}}$ & $6^{\mathrm{b}}$ & $31^{\mathrm{c}}$ \\
\hline \multicolumn{4}{|l|}{ Culling rate } \\
\hline$\leq 24 \mathrm{mo}$ & 17 & 13 & 71 \\
\hline$>24 \mathrm{mo}$ & 31 & 19 & 50 \\
\hline Overall mean & $25^{\mathrm{a}}$ & $16^{\mathrm{a}}$ & $59^{\mathrm{b}}$ \\
\hline
\end{tabular}

$\overline{{ }^{\mathrm{a} c} \mathrm{O} \text { verall proportions within a row without a common superscript are }}$ significantly different $(P<0.05)$.

${ }^{1}$ There were no differences in distributions of perceived change for each item by time since transition. 
ceived an increase, decrease, or no change in the rate of lameness or total bacterial count.

Median herd size of surveyed AMS farms was similar to the overall average herd size, 80 cows, of Canadian dairy farms (Canadian Dairy Information Centre, 2016). Farms operated with a mean number of cows per robot that fell within the recommendation of 50 to 60 cows/robot (DeLaval International AB, 2008; Hulsen and Rodenburg, 2008).

Similar to other AMS studies (Bentley et al., 2013; Woodford et al., 2015), it was more common for producers to build new facilities for the AMS than to retrofit an existing barn. Although the percentage is slowly decreasing, $72 \%$ of Canadian dairy farms still use tiestalls (Barkema et al., 2015). Changing housing system was more common in QC than other provinces, as $88 \%$ of QC dairy farms house cows in tiestalls (Canadian Dairy Information Centre, 2016). Feed bunk space per cow met industry standards of $60 \mathrm{~cm} / \mathrm{cow}$ (DFC-NFACC, 2009). Frequency of feed delivery on AMS farms was similar to a previous study; however, the average frequency of feed push-up at the bunk was double in our study (Deming et al., 2013). Stocking density met the Canadian Dairy Code of Practice's recommended best practice of $1 \mathrm{cow} /$ stall (DFC-NFACC, 2009). Stalls in our study were, on average, wider by $2 \mathrm{~cm}$ compared with what was reported in a recent study with 36 AMS farms in Canada and the United States (Westin et al., 2016). Stall widths in the current study met the minimum recommended width for cows weighing between 545 and $636 \mathrm{~kg}$, according to the Canadian Dairy Code of Practice (DFC-NFACC, 2009). Similar to the Westin et al. (2016) study, the use of rubber mats and mattresses was more common on AMS farms than the use of deep-bedding. In addition, our results for stall cleaning frequency (average of 2 times/d) was comparable to the results of the Westin et al. (2016) study, where $88 \%$ of AMS farms cleaned stalls $\geq 1$ time/d.
Having a vast amount of information provided by the AMS was documented to improve health detection in the current study, as well as other studies (see review by Barkema et al., 2015). However, some producers reported it to be more difficult to detect changes in cow health. A reason for this may be that, despite theoretically having more time to observe their cows, AMS producers may not actually be among the cows as often to visually detect changes (e.g., cows in estrous; Kruip et al., 2002). Additionally, learning to understand and use the vast amount of information collected by the robot may prove to be an exceptional challenge when transitioning to AMS (Bewley and Russell, 2010; Butler et al., 2012).

The majority of, but not all, producers changed health-management practices. It is possible that some producers who made only minor changes to healthmanagement practices did not consider their changes to be substantial enough to answer "yes" to the question "Have your health management practices changed since transitioning to AMS?"

We observed no statistical difference between the proportions of producers in our study who reported an increase, decrease, or no change in rate of lameness with the transition to AMS. A recent study, however, observed a lower prevalence of lameness in their AMS herds than previously documented in Canadian dairies with conventional milking systems (CMS; Westin et al., 2016). Producers from the current study found lameness easier to detect with AMS, which is not unexpected, as lame cows visit the AMS less frequently or are less likely to voluntarily visit the robotic unit at all than those that are not lame (Bach et al., 2007; Borderas et al., 2008; Miguel-Pacheco et al., 2014). Bach et al. (2007) showed that milk yield is negatively affected when lameness causes a decrease in AMS visits. Interestingly, most producers who perceived an increase in lameness still reported an increase in milk yield across

Table 5. Reasons for culling after transitioning to automated milking system (AMS), from most common to least $(\mathrm{n}=64)$

\begin{tabular}{lcc}
\hline Reasons for culling & $\begin{array}{c}\text { Number of } \\
\text { respondents }\end{array}$ & $\begin{array}{c}\text { Respondents } \\
(\%)\end{array}$ \\
\hline Reproduction and fertility issues & 38 & 59 \\
Udder health (mastitis, high SCC) & 33 & 52 \\
Lameness and other feet or leg issues & 30 & 47 \\
Teat placement or udder conformation & 27 & 42 \\
Behavior or temperament & 17 & 27 \\
Low production and milking speed & 16 & 25 \\
Age & 7 & 11 \\
Other causes unrelated to AMS (e.g., being unable to adapt to stalls, injury) & 6 & 9 \\
Other health issues (e.g., Johne's disease) & 2 & 3 \\
Good cull cow prices & 1 & 2 \\
Too many cows & 1 & 2 \\
\hline
\end{tabular}


the lactating herd. Hillerton et al. (2004) reported that lameness prevalence increased considerably a year after farms transitioned to AMS (unlike our study, which determined no difference in perceptions of change in lameness with time), but concluded that poorer locomotion after switching to AMS was likely due to the change in housing that had occurred at the same time as the transition. In support of that conclusion, our study determined that changing housing system at the same time as the transition to AMS resulted in higher reports of increased lameness. Thus, Canadian dairies that convert from tiestall to freestall barns at the same time as the transition to AMS should anticipate a substantial effect on cow locomotion.

Automatic detection of clinical mastitis is a challenge for AMS (see review by Hovinen and Pyörälä, 2011). Almost half the respondents of our survey indicated a decrease in clinical mastitis with the transition to AMS, and the next largest proportion of producers indicated no change. This was complementary to the findings of Hovinen et al. (2009), where the frequency of mastitis treatments decreased from 4.8/10,000 cow-days with CMS to 4.0/10,000 cow-days in AMS farms, although the difference was not significant. Furthermore, it is worth noting that a significant proportion of producers who reported a decrease in incidence of clinical mastitis also indicated an increase in milk yield $(54 \%$ of respondents). This agrees with the idea that better udder health is associated with greater milk production (Neijenhuis et al., 2010). Perceptions of change in mastitis did not differ according to time since transition. To date, no literature has documented how the rate of clinical mastitis changes according to how long a herd has been using AMS.

Geometric mean total bacterial count has been reported to increase by 4,000 to $11,000 / \mathrm{mL}$ after transitioning to AMS (Klungel et al., 2000; Rasmussen et al., 2002; de Koning et al., 2003); variation may be due to the range of transition periods used by these studies. Rasmussen et al. (2002) compared data collected 1 yr before AMS to those collected 1 yr after AMS was introduced on the same farms. Klungel et al. (2000) compared AMS farms that have been in operation for at least 1 yr to (different) farms that operated CMS. Lastly, de Koning et al. (2003) compared farm data collected up to $4 \mathrm{yr}$ before transition to data collected between 0 to $>2$ yr after the same farms transitioned to AMS. In contrast, $40 \%$ of producers in our study reported no change in bacterial count after transitioning to AMS. The studies that have reported an increase in bacterial count when transitioning to AMS are more than $10 \mathrm{yr}$ old; it is conceivable that the AMS itself and management of these systems have improved over these years. To substantiate those data, management before and after transitioning needs to be compared.

It has been hypothesized that AMS would negatively affect cow fertility, the ability to conceive a calf, as a result of an expected increase in risk of negative energy balance (NEB; Kruip et al., 2002). Kruip et al. (2002) suggested that higher milking frequencies in AMS result in greater milk yield, but not necessarily a proportional increase in feed intake, which may consequently lead to NEB. A NEB results in lower glucose and insulin levels, which are important factors in fertility (Kruip et al., 2000); however, in agreement with several experimental studies that reported no negative effects on conception rate despite increased milking frequency and milk production with AMS (Barnes et al., 1990; Devir et al., 1993; Kruip et al., 2000, 2002), a large proportion of producers in our survey reported an increase in conception rate.

Unusual udder conformation, poor temperament, and issues with legs and feet can negatively affect the usage of AMS units and may increase culling rate (Meskens et al., 2001). However, our results agree with Bentley et al. (2013), who reported little change in culling rate with the transition to AMS. Surveyed individuals in our study reported culling an average proportion of cows that were not able to adapt to the AMS compared with a previously documented culling range of 0 to $3 \%$ (Rodenburg, 2002).

A larger proportion of DeLaval respondents found health detection more difficult with AMS, perceived an increase in bacterial count, and reported a higher culling rate compared with Lely respondents. It was speculated that confounding variables, such as age of AMS units and geographical distribution of AMS brands across Canada, could have influenced these differences; however, we found no age differences between brands and the distribution of the 2 brands was similar in all provinces, except Alberta. There may be some bias due to differing levels of participation of each brand, as well as in each province. The distribution of brands and surveyed AMS farms per province were not always representative of the true distributions across Canadian provinces. In a milk quality study by de Koning et al. (2003), 32\% of the variation in total bacterial count was explained by difference between brands of AMS, although exact brands were not mentioned. To our knowledge, no literature has addressed specific brand differences for these factors or reasons for possible differences between brands of AMS.

As in most surveys, potential exists for misinterpretation of questions, recall bias (an issue of remembering accurately), and social desirability bias (the tendency to respond differently in the presence of an interviewer 
so as to appear in favorable light; Green and Thorogood, 2013). Both phone and in-person surveys were conducted, but risk for interviewer bias was minimized by asking questions strictly as they were written in the final version of the survey and only providing standardized prompts when necessary. Producers may have been influenced by post-product rationalization, a cognitive bias through which a purchaser of an expensive product looks past any product faults as a way to justify their purchase (Cohen and Goldberg, 1970). This bias may have distorted results to show more improvements on farm since transitioning to AMS. Lastly, it should be noted that the possible differences after transitioning to AMS may not be a result of just the new milking system, but also of the changes in housing and management that accompanied that change.

\section{CONCLUSIONS}

Overall transition to AMS was perceived as successful for Canadian dairy producers. With necessary changes to housing to accommodate the AMS, farms were able to increase herd size while keeping cleaning and feeding practices the same. Producers needed to change healthmanagement practices with AMS, but the majority reported health detection to be easier. Many producers reported an increased conception rate, a decrease or no change in rate of clinical mastitis, and no change in culling rate after transitioning to AMS. We found no statistical difference in the proportions of producers who perceived an increase, decrease, or no change in the rate of lameness or total bacterial count. Findings from this project provide a benchmark of the effects of AMS on important aspects of Canadian dairy farming, as well as provide producers, AMS manufacturers, veterinarians, and dairy advisors with more detailed knowledge on what to expect when transitioning to AMS.

\section{ACKNOWLEDGMENTS}

The authors thank the Dairy Farmers of Canada (Ottawa, ON, Canada), Agriculture and Agri-Food Canada (Ottawa, ON, Canada), and the BC Ministry of Agriculture (Duncan, BC, Canada) through Growing Forward 2, a federal-provincial-territorial initiative administered by the Investment Agriculture Foundation of $\mathrm{BC}$ and the University of Calgary Veterinary Medicine (UCVM; Calgary, AB, Canada) for their financial support. We also thank Alberta Milk (Edmonton, AB, Canada), Dairy Farmers of Manitoba (Winnipeg, MB, Canada), Lely Canada (Woodstock, ON, Canada), and DeLaval Canada (Peterborough, ON, Canada) for providing access to AMS producers. Thanks to Grace
Kwong at UCVM for statistical advice and the collaborators used for regional data collection: Kelsey Chapman at UCVM; Ellen Watkiss and Joe Stookey at the University of Saskatchewan (Saskatoon, SK, Canada); Lisa Gordon at the University of Guelph, Kemptville Campus (Kemptville, ON, Canada); Meagan King at the University of Guelph, Main Campus (Guelph, ON, Canada); Stephanie Dion, Jean-Michel Beaudoin, and Doris Pellerin at Laval University (Quebec City, QC, Canada); and Elsa Vasseur at McGill University (Montreal, QC, Canada).

\section{REFERENCES}

Bach, A., M. Dinarés, M. Devant, and X. Carré. 2007. Associations between lameness and production, feeding and milking attendance of Holstein cows milked with an automatic milking system. J. Dairy Res. 74:40-46.

Barkema, H. W., M. A. G. von Keyserlingk, J. P. Kastelic, T. J. G. M. Lam, C. Luby, J.-P. Roy, S. J. LeBlanc, G. P. Keefe, and D. F. Kelton. 2015. Invited review: Changes in the dairy industry affecting dairy cattle health and welfare. J. Dairy Sci. 98:7426-7445.

Barnes, M. A., R. E. Pearson, and A. J. Lukes-Wilson. 1990. Effects of milking frequency and selection for milk yield on productive efficiency of Holstein cows. J. Dairy Sci. 73:1603-1611.

Bentley, J. A., L. F. Tranel, L. L. Timms, and K. Schulte. 2013. Automatic milking systems (AMS) - Producer Surveys. Animal Industry Report: AS 659, ASL R2788. Accessed May 27, 2016. http:// lib.dr.iastate.edu/ans_air/vol659/iss1/39.

Bewley, J., and R. Russell. 2010. Reasons for slow adoption rates of precision dairy farming technologies: Evidence from a producer survey. Proc. First North Am. Conf. Precis. Dairy Manag., Toronto, Canada. Wageningen Academic Publishers, Wageningen, the Netherlands. Accessed Jan. 3, 2017. http://precisiondairy.com/ proceedings/s1bewley2.pdf.

Borderas, T. F., A. Fournier, J. Rushen, and A. M. B. de Passillé. 2008. Effect of lameness on dairy cows' visits to automatic milking systems. Can. J. Anim. Sci. 88:1-8.

Butler, D., L. Holloway, and C. Bear. 2012. The impact of technological change in dairy farming: robotic milking systems and the changing role of the stockperson. R. Agric. Soc. Engl. 173:1-6.

Canadian Dairy Information Centre. 2016. Dairy facts and figures. Accessed May 27, 2016. http://www.dairyinfo.gc.ca/index_e. php?s1=dff-fcil\&s2=farm-ferme\&s3=db-el.

Cohen, J. B., and M. E. Goldberg. 1970. Dissonance product evaluation. J. Mark. Res. 7:315-321.

de Koning, C. J. A. M. 2010. Automatic milking-Common practice on dairy farms. Proc. First North Am. Conf. Precis. Dairy Manag., Toronto, Canada. Wageningen Academic Publishers, Wageningen, the Netherlands. Accessed Jan. 3, 2017. http://www.precisiondairy. com/proceedings/s3dekoning.pdf.

de Koning, K., B. Slaghuis, and Y. Van der Vorst. 2003. Robotic milking and milk quality: Effects on bacterial counts, somatic cell counts, freezing point and free fatty acids. Ital. J. Anim. Sci. 2:291-299

DeLaval International AB. 2008. Instruction book VMS best practices [Brochure]. DeLaval International AB, Tumba, Sweden.

Deming, J. A., R. Bergeron, K. E. Leslie, and T. J. DeVries. 2013. Associations of housing, management, milking activity, and standing and lying behavior of dairy cows milked in automatic systems. J. Dairy Sci. 96:344-351.

Devir, S., J. A. Renkema, R. B. M. Huirne, and A. H. Ipema. 1993. A new dairy control and management system in the automatic milking farm: Basic concepts and components. J. Dairy Sci. 76:3607-3616.

DFC-NFACC (Dairy Farmers of Canada and the National Farm Animal Care Council). 2009. Code of Practices for the Care and Han- 
dling of Dairy Cattle. Dairy Farmers of Canada, Ottawa, Ontario, Canada.

Green, J., and N. Thorogood. 2013. Thematic content analysis. Pages 209-218 in Qualitative Methods for Health Research. 3rd ed. Sage, Los Angeles, CA.

Hansen, B. G. 2015. Robotic milking-farmer experiences and adoption rate in Jaeren, Norway. J. Rural Stud. 41:109-117.

Helgren, J. M., and D. J. Reinemann. 2006. Survey of milk quality on U.S. dairy farms utilizing automatic milking systems. Am. Soc. Agric. Biol. Eng. 49:551-556.

Hillerton, J. E., J. Dearing, J. Dale, J. J. Poelarends, F. Neijenhuis, O. C. Sampimon, J. D. H. M. Miltenburg, and C. Fossing. 2004. Impact of automatic milking on animal health. Pages 125-134 in Automatic Milking - A Better Understanding. A. Meijering, H. Hogeveen, and C. J. A. M. De Koning, ed. Wageningen Academic Publishers, Wageningen, the Netherlands.

Hovinen, M., and S. Pyörälä. 2011. Invited review: Udder health of dairy cows in automatic milking. J. Dairy Sci. 94:547-562.

Hovinen, M., M. D. Rasmussen, and S. Pyörälä. 2009. Udder health of cows changing from tie stalls or free stalls with conventional milking to free stalls with either conventional or automatic milking. J. Dairy Sci. 92:3696-3703.

Hulsen, J., and J. Rodenburg. 2008. Robotic milking [Brochure]. Roodbont Publishers, Zutphen, the Netherlands.

Jacobs, J., and J. Siegford. 2012. Invited review: The impact of automatic milking systems on dairy cow management, behaviour, health and welfare. J. Dairy Sci. 95:2227-2247.

Klungel, G. H., B. A. Slaghuis, and H. Hogeveen. 2000. The effect of the introduction of automatic milking systems on milk quality. J. Dairy Sci. 83:1998-2003.

Kruip, T. A. M., H. Morice, M. Robert, and W. Ouweltjes. 2002. Robotic milking and its effect on fertility and cell counts. J. Dairy Sci. 85:2576-2581.

Kruip, T. A. M., J. Stefanowska, and W. Ouweltjes. 2000. Robot milking and effect on reproduction in dairy cows: A preliminary study. Anim. Reprod. Sci. 60-61:443-447.

Meskens, L., M. Vandermersch, and E. Mathijs. 2001. Implication of the introduction of automatic milking on dairy farms. Deliverable D2 from EU project 'Implications of the introduction of automatic milking on dairy farms' (QLK5 2000-31006). Accessed Jan. 3, 2017. http://citeseerx.ist.psu.edu/viewdoc/download?doi=10.1.1. 198.4207\&rep=rep1\&type $=$ pdf

Miguel-Pacheco, G. G., J. Kaler, J. Remnant, L. Cheyne, C. Abbott, A. P. French, T. P. Pridmore, and J. N. Huxley. 2014. Behavioural changes in dairy cows with lameness in an automatic milking system. Appl. Anim. Behav. Sci. 150:1-8.

Molfino, J., K. Kerrisk, and S. C. García. 2014. Investigation into the labour and lifestyle impacts of automatic milking systems (AMS) on commercial farms in Australia. Pages 339-342 in Proc. 5th Australian Dairy Sci. Symp., Melbourne, Australia. Accessed Jan. 3, 2017. http://www.adssymposium.com.au/ inewsfiles/2014proceedings/ADSS2014_FULL.pdf.

Moyes, K., L. Ma, T. K. McCoy, and R. R. Peters. 2014. A survey regarding the interest and concerns associated with transition- ing from conventional to automated (robotic) milking systems for managers of small- to medium-sized dairy farms. Prof. Anim. Sci. $30: 418-422$

Neijenhuis, F., H. Hogeveen, and K. de Koning. 2010. Automatic milking systems: A Dutch study on risk factors for udder health. Proc. First North Am. Conf. Precis. Dairy Manag., Toronto, Canada. Wageningen Academic Publishers, Wageningen, the Netherlands. Accessed Jan. 3, 2017. http://precisiondairy.com/proceedings/ s8dekoning.pdf.

Rasmussen, M. D., M. Bjerring, P. Justesen, and L. Jepsen. 2002. Milk quality on Danish farms with automatic milking systems. J. Dairy Sci. 85:2869-2878.

Rodenburg, J. 2002. Robotic milkers: What, where... and how much!!?? Pages 1-18 in Proc. Ohio Dairy Management Conf., Columbus, OH. Accessed Jan. 3, 2017. https://www.researchgate. net/publication/228503938_Robotic_milkers_What_where_and_ how_much.

Rodenburg, J., and H. House. 2007. Field observations on barn layout and design for robotic milking of dairy cows. In Proc. 6th Int Dairy Housing Conf., Minneapolis, MN. The American Society of Agricultural and Biological Engineers, St. Joseph, MI.

Rousing, T., I. A. Jakobsen, J. Hindhede, I. C. Klaas, M. Bonde, and J. T. Sørensen. 2007. Evaluation of welfare indicator protocol for assessing animal welfare in AMS herds: researcher, production advisor and veterinary practitioner opinion. Anim. Welf. 16:213-216.

Tousova, R., J. Duchacek, L. Stadnik, M. Ptacek, and J. Beran. 2014 The comparison of milk production and quality in cows from conventional and automatic milking systems. J. Cent. Eur. Agric. 15:100-114.

van't Land, A., A. C. van Lenteren, E. van Schooten, C. Bouwmans, D. J. Gravesteyn, and P. Hink. 2000. Effects of husbandry systems on the efficiency and optimisation of robotic milking performance and management. Pages 167-176 in Robotic Milking, Proc. Int. Symp., Lelystad, the Netherlands. Wageningen Pers, Wageningen, the Netherlands.

Wade, K. M., M. A. P. M. van Asseldonk, P. B. M. Berentsen, W. Ouweltjes, and H. Hogeveen. 2004. Economic efficiency of automatic milking systems with specific emphasis on increases in milk production. Pages 63-68 in Automatic Milking-A Better Understanding. A. Meijering, H. Hogeveen, and C. J. A. M. De Koning, ed. Wageningen Academic Publishers, Wageningen, the Netherlands.

Westin, R., A. Vaughan, A. M. de Passillé, T. J. DeVries, E. A. Pajor, D. Pellerin, J. M. Siegford, A. Witaifi, E. Vasseur, and J. Rushen. 2016. Cow and farm-level risk factors for lameness on dairy farms with automated milking systems. J. Dairy Sci. 99:3732-3743.

Woodford, K. B., M. H. Brakenrig, and M. C. Pangborn. 2015. New Zealand case studies of automatic-milking-systems adoption. Pages 127-131 in Proc. N. Z. Soc. Anim. Prod., Dunedin, New Zealand. New Zealand Society of Animal Production Inc., Dunedin, New Zealand. 